\title{
PERAN DĀ'I DALAM MENANGGULANGI PERILAKU PATOLOGIS SEBAGAI DAMPAK NEGATIF GLOBALISASI
}

\author{
Ahmad Shofi Muhyiddin \\ Madrasah Diniyah Syafi'iyah Nurul Falah Jambu \\ Email: muhyiddinalazhar@gmail.com
}

\begin{abstract}
This study showed that the diversity of society in globalization era faced by dā'i required the effort to create the concept of relevant Islamic religious proselytizing with the diversity of its object. Therefore, the dā'i needs to know the characteristics and typology of the community being faced. Every dā'i should include the words of God (al-Qur'an) in accordance with his intellectual ability. Then the model of propaganda through a psychological approach becomes important to be applied in the globalization era. And to cope with pathological behavior as the negative impact of globalization, the dā'i in his preaching activities requires having solution for social problems faced by the majority of society in globalization era. These roles include: 1) the role of dā'i as substitute of parents. 2) The role of dā'i as a guide. 3) The role of dā'i as peer counselor.
\end{abstract}

Kajian ini menunjukkan bahwa keanekaragaman masyarakat yang akan dihadapi oleh dā'i di era globalisasi menuntut adanya upaya untuk menciptakan konsep dakwah Islam yang relevan dengan keanekaragaman obyeknya. Untuk itu, bahasa aplikasi dakwah mestilah terletak pada kearifan para petugas dakwah dengan cara mengenal karakteristik dan tipologi masyarakat yang dihadapinya. Setiap dā'i wajib membahasakan sabda Tuhan (al-Qur'an) sesuai dengan kemampuan pikiran (daya nalar) mad'ū. Maka model dakwah melalui pendekatan psikologis menjadi penting untuk diterapkan di era globalisasi. Dan untuk menanggulangi perilaku patologis sebagai dampak negatif globalisasi, maka dā'i dalam kegiatan dakwahnya dituntut untuk mempunyai peran yang solutif-partisipatif dalam menyelesaikan problematika sosial yang dihadapi oleh mayoritas masyarakat era globalisasi. Peran-peran tersebut meliputi: 1) Peran dā'i sebagai pengganti orang tua asuh. 2) Peran dā'i sebagai pembimbing. 3) Peran dā'i sebagai konselor teman sebaya.

Keywords: Dā'i, pathological behavior and negative impact of globalization 


\section{A. Pendahuluan}

Isu seputar globalisasi disinyalir mulai muncul sekitar dekade 1970an pada abad ke 20, yaitu ketika Marshall McLuhan mengeluarkan tulisannya yang berjudul "War and peace in the Global Village". Kemudian isu seputar globalisasi ini mulai marak sekitar dekade 1990-an, sehingga pada masa ini sering disebut sebagai 'așr al-'aulamah (era globalisasi) ${ }^{1}$. Ramainya diskursus seputar globalisasi pada dekade ini tidak lepas dari booming ekonomi yang melanda dunia. Era pasar bebas yang tidak lagi dibatasi oleh sekat-sekat geografi, budaya, dan ideologi politik sebuah negara, seolah sudah menjadi suatu kepastian yang harus terjadi. Meski berangkat dari persoalan ekonomi, namun globalisasi tidak hanya didominasi oleh masalah ekonomi saja, tetapi juga berkaitan dengan persoalan-persoalan lain seperti sosial, budaya, agama, politik dan pendidikan ${ }^{2}$.

Globalisasi merupakan diskursus yang banyak mengundang perdebatan masyarakat dunia, baik yang setuju (pro) maupun yang anti (kontra). Mereka yang setuju pada umumnya berangkat dari pemahaman bahwa globalisasi adalah suatu keniscayaan sejarah yang harus diterima dengan lapang dada. Sementara itu, yang anti-globalisasi melihat pada dampak negatif yang timbul dari globalisasi itu sendiri, terutama pengaruhnya yang destruktif bagi lingkungan hidup 3 .

Salah satu dampak negatif globalisasi yang senantiasa menggerogoti moral manusia adalah merebaknya perilaku patologis. Perilaku patologis berarti maladjusment yang serius di antara unsur-unsur dalam keseluruhan konfigurasi (bentuk) kebudayaan sedemikian rupa, sehingga membahayakan kelangsungan hidup suatu kelompok sosial atau yang secara serius menghambat pemuasan kebutuhan-kebutuhan asasi anggotaanggota kelompok itu yang mengakibatkan hancurnya ikatan sosial mereka ${ }^{4}$.

Bahkan sepuluh tahun terakhir ini, Indonesia bisa dikatakan sangat rawan terjadi perilaku patologis. Sebagai contoh, ancaman bahaya Napza telah berkembang pesat dan sangat merisaukan kehidupan masyarakat Indonesia. Dan yang lebih memprihatinkan, justru yang menjadi korban

1Muhammad 'Abd al-Qādir Ḥātim, "al-'Aulamah Mā Lahā wa Mā 'Alaihā", (Kairo: alHaiah al-Mișriyah al-'Āmah li al-Kitāb, 2005), hlm. 15

${ }^{2}$ Khusnul Khatimah, "Islam dan Globalisasi: Sebuah Pandangan Universalitas Islam", Jurnal Komunika STAIN Purwokerto, Vol. 3, No.1, Januari-Juni, 2009, hlm. 114

${ }^{3}$ Khusnul Khatimah, "Islam dan Globalisasi... ", h. 115

4 Soetomo, "Masalah Sosial dan Upaya Pemecahannya", (Yogyakarta: Pustaka Pelajar, 2008), hlm. 82 
penyalahgunaan Napza adalah remaja yang masih tergolong anak usia sekolah dan kebanyakan beragama islam. Mardani dalam kajiannya menyebutkan bahwa remaja yang ditahan di rumah tahanan (Rutan) Pondok Bambu dengan kasus penyalahgunaan Napza pada tahun 2002 sebanyak 300 orang. Kemudian di Lembaga Pemasyarakatan (LP) anak pria Tangerang dengan kasus penyalahgunaan Napza sebanyak 72 orang (Mardani, 2008: 3). Kemudian Dari data Departemen Kesehatan hingga Maret 2007 menyebutkan bahwa jumlah kumulatif mereka yang tertular HIV sebanyak 5.640 dan AIDS mencapai 8.988 kasus. Data akhir tahun 2006 menyebutkan bahwa penularan karena menggunakan Napza suntik mencapai 46\% kasus dan dari hubungan seksual mencapai 37\% kasus. Dari kajian yang dilakukan oleh DepKes, menyebutkan bahwa sejak Juni 2003, para pengguna narkoba suntikan atau yang disebut dengan istilah IDU (Injecting Drug User) semakin meningkat bahkan mencapai 75\%5.

Sebagai seorang muslim, sudah seyogyanya berpartisipasi dalam menanggulangi perilaku patologis yang kian marak tersebut. Penanggulangan perilaku patologis dapat dilakukan dengan cara menyampaikan, mengajarkan dan menerapkan nilai-nilai yang terkandung dalam ajaran agama Islam kepada khalayak umum. Sebagaimana yang diungkapkan oleh Ahmad 'Umar Hāsyim dalam "Manhaj al-Islām fì al'Aqīdah, al-'Ibādah wa al-Akhlāq", Islam adalah aturan Allah yang sempurna yang mencakup berbagai bidang kehidupan. Islam juga mengatur hubungan manusia dengan Allah SWT., dengan sesamanya, dan alam semesta, atas dasar ketundukan dan ketaatan kepada Allah dan RasulNya $^{6}$.

Berdakwah merupakan sebuah keharusan bagi umat muslim yang telah diciptakan oleh Allah sebagai makhluk terbaik ${ }^{7}$, karena berdakwah ialah mencerahkan, mengarahkan, dan mengontrol serta mendidik diri pribadi dan khalayak umum. Mendidik, menyelamatkan diri, memupuk solidaritas, dan mendorong kreatifitas akan membawa perubahan positif kepada keperibadian dan menemukan solusi-solusi di dalam menghadapi tantangan hidup. Dakwah adalah komunikasi yang khas, baik verbal atau non verbal, yang dilakukan oleh $d \bar{a}^{\prime} i$ sebagai upaya membentuk sikap

5Novia Rahmawati, "Konsep Perencanaan dan Perancangan Pusat Terapi dan Rehabilitasi bagi Ketergantungan Narkoba dengan Pendekatan Arsitektur Perilaku", Tesis tidak dipublikasikan, (Surakarta: Universitas Sebelas Maret, 2010), hlm. I-2

${ }^{6}$ Ahmad 'Umar Hāsyim, "Manhaj al-Islām fi al-'Aqìdah wa al-'Ibādah wa al-Akhlāq", (Kairo: Dār Nahụah Miṣr, 1997), hlm. 3

${ }^{7}$ QS. Āli 'Imrān [3]: 110 


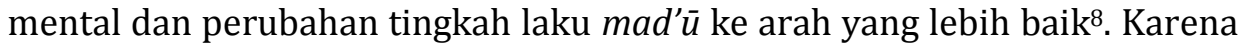
dakwah merupakan agent of social change, yaitu sebagai agen perubahan dan pembaharuan ke arah positif, maka dakwah harus mampu berperan aktif dalam menanggulangi perilaku patologis sebagai dampak negatif dari arus globalisasi tersebut.

Untuk merealisasikan hal itu, juru dakwah ( $\left.d \bar{a}^{\prime} i\right)$ diharapkan mampu melakukan gerakan dakwah yang teraupetis (bersifat menyembuhkan). Dakwah bukan saja memberikan wawasan keislaman (yang bersifat kognitif), bukan pula hanya memberikan hiburan untuk melupakan persoalan dan meredakan tekanan psikologis, namun lebih dari itu, dakwah juga diharapkan mampu membantu umat manusia dalam memahami dirinya, karena dengan memahami dirinya maka ia memahami Tuhannya, dan dengan memahami Tuhan maka ia akan terhindar dari perilaku patologis.

Berangkat dari uraian di atas, penulis tertarik untuk mengkaji tentang peran $d \bar{a}^{\prime} i$ dalam menanggulangi perilaku patologis sebagai dampak negatif globalisasi dalam tulisan ini dengan rumusan masalah: Bagaimana konsep dakwah di era globalisasi? Bagaimana konsep perilaku patologis sebagai dampak negatif globalisasi? Bagaimana peran $d \bar{a}^{\prime} i$ dalam menanggulangi perilaku patologis sebagai dampak negatif globalisasi?. Kemudian rumusan masalah ini akan diuraikan dengan menggunakan metode deskriptif-kualitatif dengan pendekatan sosio-psikologis. Dipilihnya pendekatan sosiologis karena kajian ini berhubungan dengan proses sosial, seperti: interaksi sosial, penyimpangan sosial dan globalisasi, dan berhubungan pula dengan kategori biososial, seperti: seks, keluarga, masa remaja, dan lain sebagainya ${ }^{9}$. Selain itu, kajian ini juga berhubungan dengan aspek psikologis, karena perilaku patologis yang dimaksud dalam kajian ini bersifat psikologis, bukan sosiologis ${ }^{10}$, sehingga pendekatan psikologis juga menjadi penting untuk dipakai dalam kajian ini.

${ }^{8}$ Arifin, "Psikologi Dakwah: Suatu Pengantar Studi", (Jakarta: Bumi Aksara, 1991), hlm. 16

${ }^{9}$ Michael S. Northcott, "Pendekatan Sosiologis", dalam Peter Connoly (ed), "Aneka Pendekatan Studi Agama", Terjemahan Indonesia: Imam Khoiri, cet. ke-2, (Yogyakarta: LKiS Group, 2002), hlm. 283

10 Kartini Kartono, "Patologi Sosial 1", cet. ke-11, (Jakarta: Rajawali Grafindo, 2009), hlm. 14 


\section{B. Pembahasan}

\section{Dakwah di Era Globalisasi: Menggagas Reformulasi Komponen Dakwah}

\section{a. Pengertian Dakwah}

Dakwah secara bahasa berakar dari kata "da'ā-yad'ū-da'watan" yang mempunyai pengertian: panggilan, ajakan, seruan dan undangan (almunādah), dorongan dan permintaan yang menghendaki untuk diikuti (atțalab), serta kesungguh-sungguhan (al-juhdu) demi mencapai suatu tujuan ${ }^{11}$.

Adapun secara terminologis, pengertian dakwah, menurut Muhammad al-Khuḍri Husain dalam kitabnya "ad-Da'wah Ilā al-Ișlāḥ" $(1346 \mathrm{H})$, dapat dimaknai dari aspek positif ajakan tersebut, yaitu tuntunan kepada kebaikan dan keselamatan dunia dan akhirat ${ }^{12}$. Dan menurut Syaikh 'Alī Mahfūz (1979), dakwah adalah mendorong atau memotivasi (hiśsu) manusia untuk melakukan kebaikan (al-khair) dan mengikuti petunjuk (al-hudā), memerintahkan mereka berbuat makruf (al-amr bil ma'rūf) dan mencegahnya dari perbuatan mungkar (an-nahyu 'anil munkar) agar mereka memperoleh kebahagiaan (sa'ädah) dunia ('ājil) dan akhirat $(\bar{a} j i l)^{13}$.

Selanjutnya, menurut Muhammad Abū al-Fatḥ al-Bayānūni, dakwah adalah menyampaikan Islam (tablīg al-Islām) kepada umat manusia, kemudian mengajarkannya (ta'limuhu) serta mewujudkannya (tațbīquhu) dalam segenap aspek kehidupan ${ }^{14}$.

Pengertian lebih luas disampaikan oleh Arifin, bahwasanya dakwah mengandung pengertian sebagai suatu kegiatan ajakan, baik dalam bentuk lisan, tulisan, tingkah laku dan sebagainya, yang dilakukan secara sadar dan berencana dalam usaha mempengaruhi orang lain, baik secara individual maupun secara kelompok, agar supaya timbul dalam dirinya suatu

11 Hasan 'Abd ar-Ra'ūf Muhammad al-Badawī, "Fiqh ad-Da'wah al-Islāmiyyah", (Kairo: Maktabah Azhariyyah, 1987), hlm. 7

12Muhammad al-Khuḍri Ḥusain, "ad-Da'wah ilā al-Iṣlāḥ", (Kairo: al-Maṭba'ah asSalafiyyah, 1346 H), hlm. 24-25

13 as-Syaikh 'Alī Maḥfūẓ, "Hidāyat al-Mursyidinn ilā Țuruq al-Wa'ẓi wa al-Khațābah", cet. ke-9, (Kairo: Dār al-I'tișām, 1979), hlm. 17

14 Muhammad Abū al-Fatḥ al-Bayānūnī, "al-Madkhal ilā 'Ilm ad-Da'wah: Dirāsah Manhajiyyah Syāmilah li Tārīkhi ad-Da'wah wa Ușūlihā wa Manāhijihā wa Asālībihā wa Wasāilihā wa Musykilātihā fi Daui an-Naqli wa al-'Aqli", cet. ke-3, (Beirut: Muassasah arRisālah, 1995), hlm. 17 
pengertian, kesadaran, sikap, penghayatan, serta pengamalan terhadap ajaran agama sebagai message yang disampaikan kepadanya dengan tanpa adanya unsur-unsur paksaan ${ }^{15}$.

Dari beberapa pengertian di atas, penulis mencoba merangkumnya menjadi sebuah pengertian yang singkat namun bisa dikatakan memenuhi persyaratan jāmi' dan māni'16. Dengan demikian, dakwah, menurut penulis, adalah upaya Islamisasi dalam segenap aspek kehidupan, baik secara verbal maupun non verbal, dengan menggunakan sistem dan metode tertentu, untuk mewujudkan kebahagiaan dunia dan akhirat.

\section{b. Kondisi Potensi Nafs sebagai Acuan Menjadi Dā'i}

Manusia dalam rukun dakwah merupakan bagian dari komponen dakwah yang kepadanya taklif syariat Islam diperuntukkan, baik sebagai penyeru dakwah ( $\left.d \bar{a}^{\prime} i\right)$ maupun sebagai sasaran dakwah (mad'ū). Oleh karenanya, uraian mengenai manusia sebagai sasaran dakwah tidak bisa terlepas dari potensi nafs yang dimilikinya. Karena dari nafs inilah terjadinya perilaku manusia dalam kehidupan beragama. Manusia yang memiliki kemampuan berpikir melalui penalaran, maju-mundurnya kualitas kehidupannya bergantung pada proses perubahan nafs yang dimilikinya, ke arah mana perubahan itu ditunjukkan dan berangkat dari pengaruh apa perubahan itu terjadi. Sebab, nafs terletak di antara lembah kehinaan dan samudera ketakwaan. Jika ia tertunduk di hadapan syahwat dan hawa (cinta yang salah), maka ia akan terjelembab dalam lembah kehinaan. Namun, jika ia sejalan dengan akal dan ruh, maka akan terpancar cahaya kesucian darinya dan ia pun akan tenggelam dalam samudera ketakwaan. Hamba yang memiliki nafsu terpuji inilah yang akan menduduki maqām taqwa dan wara' (tidak terlena oleh tipuan dunia) ${ }^{17}$.

Muhyī ad-Dīn Ibnu 'Arabī, sebagaimana dikutip oleh Karam Amīn Abū Karam dalam "Haqīqah al-'Ibādah 'inda Muhyī ad-Dīn Ibn 'Arabī" (1997), menuliskan:

Nafs jika dinisbatkan kepada manusia terbagi menjadi tujuh tingkatan, yaitu: (1) Nafs Ammārah, yang disebut maqām

${ }^{15}$ Arifin, "Psikologi Dakwah:... ", hlm. 7

16 Secara bahasa, jāmi' berarti mengumpulkan dan māni' berarti melarang. Dalam ilmu mantiq, jāmi' berarti mengumpulkan semua satuan yang dita'rifkan ke dalam ta'rif. Sedangkan māni' berarti melarang masuk segala satuan dari yang dita'rifkan ke dalam ta'rif tersebut. Maka ta'rif tidak boleh lebih umum atau lebih khusus dari yang dita'rifkan.

17 Muhyī ad-Dīn Ibnu 'Arabī, "al-Futūhāt al-Makkiyyah", Taḥqīq: 'Uṡmān Yahyyā, cet. ke-2, (Kairo: al-Haiah al-Mișriyah al-'Āmah li al-Kitāb, 1985), jilid. 2/ hlm. 196 
zulmah al-ag்yār (tempat kezaliman pada orang-orang lain). Nafs ini mendorong pada perilaku tercela dan buruk karena kecondongan wataknya pada keinginan-keinginan jasad (biologis). Nafs jenis ini merupakan peringkat nafs terendah. (2) Nafs Lawwāmah, yang disebut maqām hudūs al-anwār (tempat munculnya cahaya-cahaya). Nafs ini muncul setelah mengikuti dorongan nafs ammärah segera muncul kesadaran pada dirinya dengan menyesali apa yang telah dilakukannya. Nafs ini lebih atas derajatnya daripada nafs yang pertama. (3) Nafs Mulhamah, yang disebut maqām dark al-asrār fi al-khair wa al-syar (tempat mengetahui beragam rahasia kebaikan dan keburukan). Nafs ini berkemampuan mengetahui dan membedakan antara sesuatu yang baik dengan sesuatu yang buruk dan menjadi basis pertimbangan potensi memilih untuk mengambil putusan pilihan perilaku. (4) Nafs Muțmainnah, yang disebut sebagai maqām at-tawāzun an-nafsī (tempat keseimbangan jiwa). Nafs ini berkemampuan mendorong kepada perilaku terpuji dan baik, dengan menggantikan sifatsifat yang tercela, seperti rasa cinta, kasih sayang, lemah lembut dan lain sebagainya. (5) Nafs Rädiyah, yang disebut sebagai maqām nail al-wașl (tempat memperoleh hubungan). Nafs ini berkemampuan membentuk ketenangan jiwa dengan menundukkan dorongan dan sifat-sifat tercela dalam dirinya. Ia merasa betah dan rela dalam menjalani kewajiban dan meninggalkan segala larangan yang akan mengotori dirinya. (6) Nafs Mardiyyah, yang disebut dengan maqām tajallī almawāhib al-Ilähiyyah (tempat tampaknya segala pemberian Tuhan). Nafs ini berkemampuan dalam mewujudkan situasi jiwa yang riḍa dan ikhlas dalam menerima semua yang ditaklifkan Allah SWT. pada dirinya. Untuk itu Allah menyebut keduanya dalam firman-Nya: (رَاضِيَةَ مَرْضِيَّةً ) karena keteguhan Imannya. Ia ridha dengan apapun yang ditakdirkan oleh Tuhannya sehingga Tuhan pun meridhainya. Maka dari itulah Allah pun menyerunya agar senantiasa bersama-sama dengan-

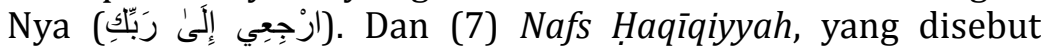
dengan maqām al-Haqīqah al-Muhammadiyyah (tempat hakikat Muhammad). Nafs jenis ini pemahamannya didasarkan 
atas beberapa ayat Al-Qur'an, antara lain : QS. an-Nisa [4]: 80, QS. al-Anfāl [8]: 17, dan QS. al-Fath [48]: $10^{18}$.

Dari sedikit uraian di atas, sepertinya Ibnu 'Arabī meyakini adanya pengaruh dan mempengaruhi antara nafs yang bersifat immateri dengan jasad yang bersifat materi. Di sinilah peranan dakwah berlangsung dalam sistem kehidupan psikologis manusia.

Manusia sebagai $d \bar{a} ' i$ dan mad'ū berhubungan dengan kualitas dan kuantitas aktualisasi potensi nafs yang dimilikinya. Manusia berhak menjadi $d \bar{a} ' i$ jika ia minimal berada dalam posisi nafs muțainnah. Sebab, dā'i bertugas mengajak kepada kebaikan (yad'ü ila al-khair), sementara kebaikan hanya bisa diketahui oleh orang yang sudah mengenal Tuhannya. Orang mulai bisa mengenal Tuhannya, menurut Ibnu 'Arabī, ketika minimal berada dalam posisi nafs muțainnah. Dan jika manusia belum sampai pada posisi nafs muțmainnah, maka ia masih membutuhkan bimbingan dan bantuan untuk meningkatkannya. Manusia yang demikian ini adalah $\operatorname{mad}^{\prime} \bar{u}^{19}$.

Selanjutnya, dakwah bagi umat Islam, sesungguhnya menjadi kewajiban yang menyeluruh. Setidaknya, umat Islam yang dimaksud adalah yang termasuk dalam kategori mukallaf (individu yang sudah bisa dikenai beban tanggungjawab) dan mumayyiz (individu yang telah mampu membedakan antara yang benar dan salah, serta antara baik dan buruk). Menjadi umat Islam pada hakekatnya berkewajiban untuk berdakwah, sehingga menjadi Muslim bisa diidentikkan sebagai $d \bar{a}^{\prime} i$ atau juru dakwah. Akan tetapi, sebagai manusia, umat Islam juga mempunyai nafs yang derajatnya bisa berubah-ubah sehingga berpengaruh pada tingkat keimanannya. Oleh karena itu, menjadi Muslim juga membutuhkan bimbingan secara terus menerus agar nafsnya sejalan dengan akal dan ruh, sehingga akan terpancar cahaya kesucian darinya. Dengan demikian, menjadi Muslim, selain bisa diidentikan sebagai $d \bar{a}^{\prime} i$, juga bisa diidentikan sebagai mad'ü atau sasaran dakwah, menurut proporsi dan kapasitas masing-masing. Itulah mengapa Allah SWT. memerintahkan manusia untuk menjaga dirinya terlebih dahulu dari api neraka, baru kemudian menjaga keluarganya ${ }^{20}$.

18 Karam Amīn Abū Karam, "Haqīqah al-'Ibādah 'inda Muhyī ad-Dīn Ibn 'Arabī", (Kairo: Dār al-Amīn, 1997), hlm. 74

19 Muhyī ad-Dīn Ibnu 'Arabī, "Tafsīr al-Qur'ān al-Karīm (Tafsīr Ibn 'Arabī)", Tahqīiq: 'Abd al-Wāris̀ Muhammad 'Alī, (Beirut: Dār al-Kutub al-'Ilmiyyah, 2006), jilid. 1/ hlm. 139

20 QS. At-Tahrīm [66]: 6 


\section{c. Mengenal Mad'ū dan Kondisinya}

Mad'ū (objek dakwah) adalah orang yang menjadi sasaran dakwah (man tuwajjahu ilaihi ad-da'wah) ${ }^{21}$. Yaitu semua manusia tanpa terkecuali22. Hal ini didasarkan pada firman Allah SWT.:

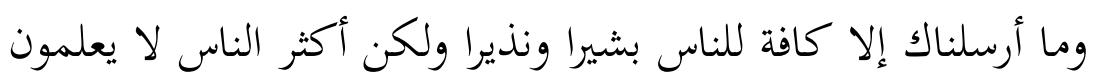

"Dan Kami tidak mengutus kamu, melainkan kepada umat manusia seluruhnya sebagai pembawa berita gembira dan sebagai pemberi peringatan, tetapi kebanyakan manusia tidak mengetahui"23.

Mengenal mad'ū merupakan salah satu prinsip utama yang harus dimiliki oleh seorang dā'i karena merupakan tuntutan logis dalam menjalankan aktivitas dakwah. Dengan mengenal mad'ū berdasarkan situasi dan kondisinya, dakwah pun dapat diaplikasikan secara efektif. Kegiatan dakwah dalam prinsip ini sering diibaratkan dengan kegiatan dokter yang mengobati orang sakit, di mana harus mengetahui jenis penyakit sebelum mengobati. Begitu juga dakwah, proses dakwah sulit berhasil tanpa adanya analisis terhadap sasaran dakwahnya terlebih dahulu ${ }^{24}$.

Oleh karena ruang lingkup mad'ū atau sasaran dakwah sangat luas, yaitu mencakup keseluruhan manusia, baik diri sendiri (nafsī) maupun orang lain (gair), baik perorangan (fardī) maupun kelompok (jamä'ah), maka analisis terhadap mad'ū atau sasaran dakwah dan kondisinya didasarkan pada macam-macam mad'ū tersebut, antara lain:

\section{1) Mad'ū Nafsī dan Kondisinya}

Manusia adalah makhluk unik yang mempunyai banyak sebutan. Sedikitnya ada tiga kelompok istilah yang digunakan al-Qur'an dalam menjelaskan manusia secara totalitas, baik fisik maupun psikis. Pertama, kelompok kata al-basyar (sebutan umum minus karakteristik), kedua, kelompok kata al-insān dengan berbagai macam akar katanya (makhluk

21 Muhammad Abū al-Fatḥ al-Bayānūnī, "al-Madkhal ilā 'Ilm ad-Da'wah: ...", hlm. 169

22 'Abd al-Karīm Zaidān, "'Ușūl ad-Da'wah", cet. ke-3, (Bag̉dād: Dār at-Turāś, 1976), hlm. 358

${ }^{23}$ QS. Saba [34]: 28

${ }^{24}$ Muhammad 'Abd al-'Azīz Ibrāhīm Dāud, "at-Tabșurah fi Fiqh ad-Da'wah wa adDā'iyah", (Zaqāziq: Maktabah Jāmi'ah al-Azhar, T.tt), hlm. 176 
psikologis) dan ketiga, kelompok kata banī ādam (makhluk biologis). Masing-masing istilah ini memiliki intens makna yang beragam dalam menjelaskan manusia. Perbedaan itu dapat dilihat dari konteks-konteks ayat yang menggunakan istilah-istilah tersebut 25 .

Nama al-insān berasal dari kata nasiya-yansā-nisyān (lupa), al-uns, alins, anasa, anusa, anisa (mesra, ramah, dan lembut), dan nāsa-yanūsu (bergejolak). Insan mengandung pengertian makhluk psikologis yang memiliki tabiat kemesraan, pelupa dan bergejolak. Jadi dari segi bahasa saja sudah tergambar kualitas psikologis manusia yang dinamis antara mesra dan benci, sadar dan lupa, dan bergejolak dan tenang26.

Manusia, sebagaimana termaktub di atas, berhak menjadi $d \bar{a}^{\prime} i$ jika ia minimal berada dalam posisi nafs muțmainnah, karena dengan tingkatan nafs tersebut, ia memiliki kualitas psikologis yang mesra, sadar, dan tenang27. Dan sebaliknya, jika manusia belum sampai pada posisi nafs muțmainnah, maka ia masih membutuhkan bimbingan dan bantuan untuk meningkatkannya, karena pada tingkatan ini, ia masih diliputi oleh kualitas psikologis yang benci, lupa, dan bergejolak. Manusia yang demikian ini

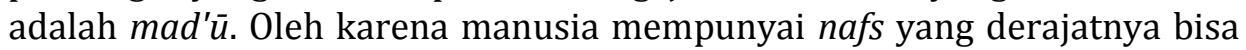
berubah-ubah sehingga berpengaruh pada tingkat keimanannya ${ }^{28}$, maka menjadi Muslim juga membutuhkan bimbingan secara terus menerus agar nafsnya sejalan dengan akal dan ruh, sehingga akan terpancar cahaya kesucian darinya. Itulah mengapa Allah SWT. memerintahkan manusia untuk menjaga dirinya (mendakwahi dirinya) terlebih dahulu dari api neraka, baru kemudian menjaga keluarganya (mendakwahi keluarganya). Allah SWT. berfirman:

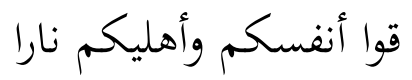

"Peliharalah dirimu dan keluargamu dari api neraka"29.

Dengan demikian yang dimaksud dengan mad'ū nafsī adalah menjadikan atau memposisikan diri sendiri sebagai mad'ū atau sasaran dakwah dengan maksud mendidik dan membimbing diri sendiri agar bisa

${ }^{25}$ Achmad Mubarok, "Psikologi Dakwah: Membangun Cara Berfikir dan Merasa", (Malang: Madani Press, 2014), hlm. 55

26 Achmad Mubarok, “Psikologi Dakwah: ...", hlm. 55-56

27 Muhyī ad-Dīn Ibnu 'Arabī, “Tafsìr al-Qur'ān al-Karīm ...”, jilid. 1/hlm. 139

28 Muhyī ad-Dīn Ibnu 'Arabī, "al-Futūḥāt al-Makkiyyah", Taḥqīq: Nawwāf al-Jarrāḥ, cet. ke-2, (Beirut: Dār Șādir, 2007), jilid. 3/hlm. 136

${ }^{29}$ QS. At-Tahrīm [66]: 6 
menjadi seorang Muslim yang memiliki kepribadian-kepribadian $d \bar{a}^{\prime} i$ sebagaimana termaktub di atas.

\section{2) Mad'ū Ǵair dan Kondisinya}

Pengertian ġair, menurut Ibnu Manzūr, adalah pengecualian sesuatu dari sesuatu, atau menentukan sesuatu. Paling sedikit dari Ġair terdiri dari satu orang (sebagaimana pendapat Mujāhid), atau dua orang (sebagaimana pendapat 'Ațâ'), atau sekelompok manusia, baik kelompok kecil maupun kelompok besar ${ }^{30}$. Jadi, yang dimaksud dengan mad'ü gair dalam pembahasan ini adalah menjadikan atau memposisikan orang lain sebagai mad'ú atau sasaran dakwah dengan maksud membimbing dan mengajarkan Islam kepadanya agar bisa menjadi pribadi yang khairu ummah. Dengan demikian dapat dikatakan bahwa mad'ū gair terbagi menjadi dua, yaitu: mad'ū fardī (sasaran dakwah yang terdiri dari satu orang, atau dua orang, atau kelompok kecil) dan mad'ü jamä'ah (sasaran dakwah yang terdiri dari kelompok besar).

Kemudian, dalam menghadapi mad'ū gair, seorang $d \bar{a} ' i$ seyogyanya mengetahui bahwa tidak selamanya tugas dalam mengajak pada kebaikan akan berhasil dan dapat diterima oleh setiap orang. Seorang dā'i juga seyogyanya menyadari bahwa mad'ū ġair yang akan dihadapi itu memiliki keunikan, karakter dan kondisi yang beraneka ragam yang dipengaruhi oleh faktor psikologis dan sosiokultural.

Faktor psikologis dapat berupa kecenderungan-kecenderungan potensi nafs, baik yang bersifat positif ataupun negatif. Hal itu dikarenakan Allah SWT. menciptakan dalam jiwa manusia empat potensi, yaitu: a) potensi syahwat kebinatangan (al-quwwah as-syahwaniyyah albahimiyyah) yang bertugas mempengaruhi dan mengajak manusia untuk memuaskan dirinya dengan kenikmatan-kenikmatan yang didorong oleh syahwat manusia, b) potensi nafsu kebuasan (al-quwwah al-gadabiyyah assabu'iyyah) yang selalu membujuk manusia untuk melakukan perilaku munkar, keburukan, kejahatan dan perbuatan yang menggangu kesejahteraan orang lain, c) potensi anggapan estimasi syaitan (al-quwwah al-wahmiyyah as-syaitāniyyah) yang bertugas mempengaruhi manusia untuk melakukan perilaku fahsy $\bar{a}^{\prime}$ dan munkar secara bersamaan. Inilah yang disebut dengan perilaku bagy (kezaliman yang melampaui batas), dan d) potensi kecerdasan malaikat (al-quwwah al-'aqliyyah al-malakiyyah).

30 Ibnu Manzūū, "Lisān al-'Arab", Taḥīq: 'Abdullāh 'Alī al-Kabīr, Muhammad Ahmad Hasbullāh dan Hāsyim Muhammad as-Syāżilī, (Kairo: Dār al-Ma'ārif, T.tt), hlm. 2723 dan 3325 
Untuk potensi terakhir ini tidak dibutuhkan pengendalian. Namun, untuk tiga pontensi sebelumnya, semuanya membutuhkan pengendalian, bimbingan, dan dakwah ${ }^{31}$.

Sedangkan faktor sosiokultural dapat dipengaruhi oleh kondisi lingkungan, politik, dan ideologi. Oleh karena perbedaan kondisi lingkungan, politik dan ideologi tersebut, maka ketika dakwah disampaikan, reaksi mad'ū terhadap pesan dakwah pun berbeda-beda, ada yang menerima dengan senang hati dan mengamalkannya (ummah alistijäbah), ada juga yang menerima namun tidak mengamalkan, dan ada pula yang mengingkari dakwah secara keseluruhan (ummah ad-da'wah) ${ }^{32}$.

Akan tetapi menurut penulis, faktor dominan yang dapat mempengaruhi kondisi mad'ū adalah faktor psikologis. Hal itu dikarenakan pada dasarnya manusia lebih cenderung kepada kebaikan, hanya saja daya tarik keburukan lebih kuat dibanding daya tarik kebaikan ${ }^{33}$. Maka dari itu, penulis kemudian berasumsi bahwa dakwah sebagai proses tagīir (perubahan), ișlāh (perbaikan) dan tajdìd (pembaruan) kehidupan mad'ū hendaknya lebih ditekankan pada aspek aktualisasi potensi positif nafs. Hal ini juga sejalan dengan pendapat beberapa ilmuwan sosial mengenai terjadinya perubahan sosial, misalnya Wilbert Moore (1967) dan Evert E. Hagen (1962), seperti dikutip Syukriadi Sambas dalam disertasinya ${ }^{34}$, yang berpandangan bahwa "perubahan sosial tidak akan terjadi tanpa perubahan dalam kepribadian yang akan menimbulkan perubahan pola-pola perilaku dan interaksi sosial". Dengan demikian, sungguh sangat beruntung orangorang yang dapat mensucikan nafsnya (dengan mengaktualisasikan potensi positifnya), dan sungguh sangat merugi orang-orang yang mengotori nafsnya (dengan membiarkannya terjebak dalam aliran potensi negatif) ${ }^{35}$.

\section{d. Tujuan Dakwah}

Setiap tindakan yang dilakukan secara sadar oleh manusia senantiasa memiliki tujuan tertentu yang akan dicapai. Dakwah sebagai bagian dari tindakan yang mulia sudah barang tentu memiliki tujuan. Tujuan dakwah,

\footnotetext{
${ }^{31}$ Muhammad Fakhr ad-Dīn ar-Rāzī, "Mafātị̣ al-Ġaib”, (Beirut: Dār al-Fikr, T.tt), jilid. 20/hlm. 106

32 Muhammad Abū al-Fath al-Bayānūnī, "al-Madkhal ilā 'Ilm ad-Da'wah: ...", hlm. 172174

33 QS. Asy-Syams [91]: 8

34 Syukriadi Sambas, "Pemikiran dakwah Muhammad Abduh dalam Tafsir al-Mannar", Disertasi tidak dipublikasikan, (Jakarta: Sekolah Pascasarjana UIN Syarif Hidayatullah, 2009), hlm. 123

35 QS. Asy-Syams [91]: 9-10
} 
menurut penulis, secara garis besar dapat dikelompokkan menjadi dua macam kategori, antara lain:

Pertama, tujuan ideal dakwah. Tujuan ideal dakwah adalah tujuan yang menjadi impian kebanyakan umat manusia, baik individu maupun sosial. Tujuan ini dapat dipahami dari keinginan kebanyakan manusia dalam setiap doanya, yaitu memperoleh kebaikan dunia dan akhirat. Kebaikan menurut Ibnu 'Arabī'36 adalah mengenal Allah dan sampai kepada-Nya (ma'rifatullah wa al-wușūl ilaihi). Dengan demikian, esensi tujuan ideal dakwah adalah mengajak manusia untuk mengenal Allah di dunia. Dengan mengenal Allah, manusia akan terbebas dari hijab yang menghalanginya dari Tuhannya, sehingga ia menyadari bahwa segala sesuatu yang ada di dunia ini hanyalah penampakan-Nya, sebab satusatunya wujud hanyalah Allah SWT.. Setelah itu, ketika di akhirat, ia mendapatkan riḍa-Nya sehingga bisa sampai (wușūl) kepada-Nya ${ }^{37}$. Dengan demikian, tujuan ideal dakwah bukanlah memaksa seseorang untuk mengikuti apa yang diyakini oleh juru dakwah, akan tetapi mengembalikan manusia pada fitrah yang telah dianugerahkan Allah kepadanya sesuai dengan peruntukannya. Dengan kata lain, tujuan ideal dakwah adalah membentuk pribadi Muslim yang paripurna.

Kedua, tujuan umum dakwah. Tujuan umum dakwah mengacu pada kehidupan manusia sebagai makhluk sosial yang menuntut adanya interaksi satu sama lain. Kemudian, berangkat dari teori tajalli, semua eksistensi yang ada di dunia pada hakikatnya merupakan teofani atau pancaran dari Tuhan ${ }^{38}$. Kesadaran semacam ini nantinya akan mengantarkan manusia kepada berakhlak dengan akhlak Allah (attakhalluq bi akhläqillāh). Takhalluq di sini bukan berarti meniru secara aktif nama-nama Allah karena tugas ini di luar kemampuan manusia. Takhalluq berarti menafikan sifat-sifat kemanusiannya dan menegaskan sifat-sifat Allah yang telah termanifestasi dalam dirinya di setiap kehidupannya ${ }^{39}$. Dan di antara akhlak Allah adalah Maha Pengasih dan Maha Penyayang. Seseorang yang senantiasa menghiasi dirinya dengan akhlak ini, dapat dipastikan ia akan memiliki sifat penuh kasih sayang, baik terhadap sesama manusia maupun terhadap makhluk lain. Dengan demikian, tujuan umum dakwah adalah mewujudkan sikap takhalluq bi akhlāqillāh dalam tatanan kehidupan sosial.

36 Muhyī ad-Dīn Ibnu 'Arabī, “Tafsīr al-Qur'ān al-Karīm ...”, jilid. 1/hlm. 139

37 Muhyī ad-Dīn Ibnu 'Arabī, "Tafsīr al-Qur'ān al-Karīm ...”, jilid. 1/hlm. 96

38 Kautsar Azhari Noer, "Ibn 'Arabi: Wahdat al-Wujud dalam Perdebatan", (Jakarta: Paramadina, 1995), hlm. 61

${ }^{39}$ Kautsar Azhari Noer, "Ibn 'Arabi: ...", hlm. 139-140 


\section{Perilaku Patologis sebagai Dampak Negatif Globalisasi}

\section{a. Pengertian Perilaku}

Menurut Sumardi Suryabrata, seperti dikutip oleh Dicky Surachman dalam tesisnya, perilaku adalah semua kegiatan atau aktivitas manusia, baik yang diamati langsung, maupun yang tidak dapat diamati oleh pihak luar. Jadi, Perilaku adalah segenap manifestasi hayati individu dalam berinteraksi dengan lingkungan, mulai dari perilaku yang paling nampak sampai yang tidak tampak, dari yang paling dirasakan sampai yang paling tidak dirasakan. Perilaku manusia merupakan hasil dari segala macam pengalaman serta interaksi manusia dengan lingkungannya yang terwujud dalam bentuk pengetahuan, sikap dan tindakan. Dengan kata lain, perilaku merupakan respon atau reaksi seorang individu terhadap stimulus yang berasal dari luar maupun dari dalam dirinya. Respon ini dapat bersifat pasif (tanpa tindakan berpikir, berpendapat, bersikap) maupun aktif (melakukan tindakan) ${ }^{40}$.

Perilaku seseorang dikelompokkan ke dalam perilaku wajar dan perilaku menyimpang. Perilaku seseorang dinilai normal dapat dilihat dari daya integrasi, ada tidaknya simtom gangguan, kriteria psikoanalisis dan determinan sosio-kultural. Namun demikian, perilaku abnormal kadang kala terlihat begitu mencolok karena berbeda dengan tingkah laku biasa pada umumnya, sehingga ketika seseorang melihatnya, ia tidak akan raguragu lagi untuk menyebutnya sebagai abnormal ${ }^{41}$. Adapun Jalaludin Rahmat berpendapat bahwa masalah normal dan abnormal tentang tingkah laku, dalam nafsiologi ditentukan oleh nilai dan norma yang sifatnya universal. Orang yang disebut normal adalah orang yang seoptimal mungkin melaksanakan iman dan amal saleh di segala tempat. Kebalikan dari ketentuan itu adalah abnormal, yaitu sifat-sifat zalim, fasik, syirik, kufur, nifak, dan sejenis itu ${ }^{42}$.

40 Dicky Surachman, "Pengaruh Penyimpangan Seksual dalam perilaku dan Pola Pikir Siswa terhadap Prestasi Belajar pada Mata Pelajaran Pendidikan Agama Islam di SMPN 1 Kabupaten Cirebon", Tesis tidak dipublikasikan, (Cirebon: Program Pascasarjana IAIN Syekh Nurjati, 2011), hlm. 11-12

41 Dicky Surachman, "Pengaruh Penyimpangan Seksual ..", hlm. 20.

42 Jalaluddin Rakhmat, "Psikologi Komunikasi", (Bandung: Remaja Karya, 2009), hlm. 


\section{b. Pengertian Perilaku Patologis}

Patologi berasal dari kata pathos yang artinya penderitaan, penyakit, dan kata logos yang artinya ilmu, jadi patologi berarti ilmu tentang penyakit. Jika ditambah huruf "s" di belakangnya maka menunjukkan pada kondisinya, jadi patologis berarti kondisi atau keadaan patologisnya. Adapun menurut para sosiolog, sebagaimana disebutkan Kartini Kartono, mereka mendefiniskan perilaku patologis sebagai:

Semua tingkah laku yang bertentangan dengan norma kebaikan, stabilitas lokal, pola kesederhanaan, moral, hak milik, solidaritas kekeluargaan, hidup rukun bertetangga, disiplin, kebaikan dan hukum formal ${ }^{43}$.

Pengertian yang senada juga dikemukakan oleh Gillin (1954), yang juga melihat perilaku patologis sebagai kondisi masyarakat yang maladjustment (ketidakmampuan menyesuaikan dri). Dikatakannya, bahwa:

Perilaku patologis berarti maladjusment yang serius di antara unsur-unsur dalam keseluruhan konfigurasi (bentuk) kebudayaan sedemikian rupa, sehingga membahayakan kelangsungan hidup suatu kelompok sosial atau yang secara serius menghambat pemuasan kebutuhan-kebutuhan asasi anggota-anggota kelompok itu yang mengakibatkan hancurnya ikatan sosial mereka ${ }^{44}$.

Teori ini mendasarkan diri pada analogi organisme biologi dengan organisme sosial, masalah sosial dianalogikan dengan penyakit ${ }^{45}$. Yang dimaksud penyakit adalah penyimpangan dari keadaan normal. Deviasi atau penyimpangan diartikan sebagai tingkah laku yang menyimpang dari tendensi sentral atau ciri-ciri karakteristik rata-rata dari rakyat kebanyakan (populasi). Selain itu ada yang disebut diferensiasi yang diartikan sebagai tingkah laku yang berbeda dari tingkah laku umum. Misalnya, kejahatan adalah semua bentuk tingkah laku yang berbeda dan

${ }^{43}$ Kartini Kartono, "Patologi Sosial 1", hlm. 1

44 Soetomo, "Masalah Sosial dan Upaya Pemecahannya", (Yogyakarta: Pustaka Pelajar, 2008), hlm. 82

45 Kenneth J. Neubeck, Mary Alice Neubeck, Glasberg, and Davita Silfen, "Social Problem (a Critical Approach)", (New York: McGraw-Hill, 1980), hlm. 4 
menyimpang dari ciri-ciri karakteristik umum, serta bertentangan dengan hukum, atau melawan peraturan yang legal. Sedang kejahatan itu sendiri mencakup banyak variasi tingkah laku dan sangat heterogen sifatnya, sebab bisa dilakukan oleh pria, wanita, anak-anak, tua, remaja, maupun usia sangat muda ${ }^{46}$.

Dari sedikit uraian di atas dapat dikatakan bahwa perilaku patologis adalah semua bentuk tingkah laku yang dianggap oleh sebagian besar warga masyarakat sebagai mengganggu, tidak dikehendaki, berbahaya, dan merugikan orang banyak karena melanggar atau memperkosa adat istiadat masyarakat (dan adat-istiadat tersebut diperlukan untuk menjamin kesejahteran hidup bersama). Jadi jelaslah bahwa adat-istiadat dan kebudayaan itu mempunyai nilai pengontrol dan nilai sanksional terhadap tingkah laku anggota masyarakatnya. Maka tingkah laku yang dianggap sebagai tidak cocok, melanggar norma dan adat-istiadat, atau tidak terintegrasi dengan tingkah laku umum dianggap sebagai perilaku patologis.

\section{c. Perilaku Patologis sebagai Dampak Negatif Globalisasi}

Era globalisasi, menurut Azyumardi Azra, adalah zaman yang penuh paradoks dari abad sains dan teknologi (the age of science and technology), dan abad kecemasan (the age of anxity) ${ }^{47}$. Globalisasi diakui telah mendatangkan kekayaan secara material, tetapi sangat kering dan miskin secara etika dan moral. Segala sesuatu cenderung dilihat dari sudut kemajuan material. Perasaan kemanusiaan siap dikorbankan demi memperoleh keuntungan material sebanyak-banyaknya. Contoh kongkret, pada tingkat penguasa dan pengusaha, seringkali mereka memandang rakyat atau karyawan sebagai angka-angka yang bisa dimanipulasikan untuk kepentingannya. Mereka tidak terlihat lagi sebagai sosok yang mempunyai perasaan. Ini sesungguhnya merupakan degradasi dan reduksi terhadap kualitas hidup manusia. Konsekuensinya, nilai-nilai luhur kemanusiaan, kebersamaan, solidaritas dan persaudaraan sebagai sesama manusia kurang mendapat perhatian yang wajar dalam masyarakat era globalisasi ${ }^{4849}$. Walhasil, masyarakat era globalisasi, seperti kisah-kisah

46 Kartini Kartono, "Patologi Sosial 1", hlm. 11

47 Azyumardi Azra, "Konflik Baru Antarperadaban: Globalisasi, Radikalisme, dan Pluralitas", (Jakarta: PT. Raja Grafindo Persada, 2002), hlm. 69

48 Mereka yang memiliki hati, namun tidak dapat memahami ayat-ayat Allah, memiliki mata, tapi tidak berfungsi untuk melihat tanda-tanda kebesaran Allah, dan memiliki telinga, akan tetapi tidak dipergunakan mendengarkan ajakan atau nasehat 
yang sering dilaporkan dalam buku-buku psikologi bahkan film dan drama TV, seringkali menghadapi persoalan makna hidup, karena tekanan yang amat berlebihan kepada segi keterikatan (attachment) terhadap peristiwaperistiwa tragis dalam kehidupan pribadi dan sosial. Maka tidak mengherankan jika mereka seringkali menjadi gelisah dan merasakan ketegangan batin. Kegelisahan dan ketegangan batin itu mendorongnya untuk melakukan sesuatu, supaya dapat menghilangkan rasa yang tidak enak itu. Apabila tidak mampu memenuhinya, terkadang ia lalu mencari kepuasan dengan cara yang tidak wajar, misalnya mengkonsumsi narkoba, memfitnah, mencuri, berzina, mabuk-mabukan, pendusta, menganiaya diri atau orang lain, menyakiti badan orang atau hatinya, dan berbagai perilaku patologis lainnya ${ }^{50}$. Dengan demikian jelaslah bahwa kemunculan perilaku patologis merupakan salah satu dampak negatif globalisasi.

\section{Peran $D \bar{a}$ 'i dalam Menanggulangi Perilaku Patologis}

\section{a. Teori Peran}

Peran merupakan aspek yang dinamis dari kedudukan (status). Artinya, seseorang telah menjalankan hak-hak dan kewajibankewajibannya sesuai dengan kedudukannya, maka orang tersebut telah melaksanakan suatu peran ${ }^{51}$. Adapun dalam Kamus Besar Bahasa Indonesia, peran mempunyai arti seperangkat tingkah laku yang sangat penting karena dianggap berpengaruh dalam kehidupan, dalam menyumbangkan pikiran dan tenaga demi tercapainya suatu tujuan, sehingga diharapkan agar dimiliki oleh orang yang berkedudukan dalam masyarakat ${ }^{52}$.

David Berry, dengan mengutip Grass Masson dan A.W. Mc. Eachern, mendefinisikan "peran" sebagai seperangkat harapan-harapan yang dikenalkan pada individu yang menempati kedudukan sosial tertentu ${ }^{53}$. Selain itu, dalam perspektif psikologi sosial, peran didefinisikan dengan

kebajikan, maka mereka itu laksana binatang, bahkan lebih sesat dar itu. Lihat QS. Al-A'raf (7): 179.

49 Muhammad 'Abd al-Qādir Ḥātim, "al-'Aulamah Mã Lahā wa Mā 'Alaihā", hlm. 435

50 Kartini Kartono, "Patologi Sosial 1", hlm. 72

51 J. Dwi Narwoko dan Bagong Suyanto, "Sosiologi: Teks Pengantar dan Terapan", (Jakarta: Kencana, 2007), hlm. 158

52 Departemen Pendidikan Nasional, "Kamus Besar Bahasa Indonesia", (Jakarta: Balai Pustaka, 2002), hlm. 667

53 David Berry, "Pokok-Pokok Pikiran dalam Sosiologi", (Jakarta: Raja Grafindo Persada, 1995), hlm. 99 
"suatu perilaku atau tindakan yang diharapkan oleh orang lain dari seorang yang memiliki suatu status di dalam kelompok tertentu"54. Harapanharapan yang dimaksud, merupakan imbangan dari norma-norma sosial, oleh karena itu dapat dikatakan peran-peran tersebut ditentukan oleh norma-norma di dalam masyarakat, artinya seseorang diwajibkan untuk melakukan hal-hal yang diharapkan oleh masyarakat di dalam pekerjaannya.

\section{b. Peran $D \bar{a}$ 'i dalam Menanggulangi Perilaku Patologis}

$D \bar{a} \prime i$ adalah orang yang menyampaikan Islam, mengajarkannya, dan berupaya untuk mewujudkannya dalam setiap aspek kehidupan manusia ${ }^{55}$. As-Syaikh 'Alī Maḥfūz, menyebut $d \bar{a} ' i$ sebagai penerus para Nabi yang mengemban tugas mulia yang diamahkan Allah kepadanya untuk disampaikan kepada umat manusia. Dengan demikian, $d \bar{a}^{\prime} i$ adalah salah satu faktor dalam kegiatan dakwah yang menempati posisi yang sangat penting dalam menentukan berhasil atau tidaknya kegiatan dakwah ${ }^{56}$.

Kemudian, istilah menanggulangi berasal dari kata "tanggulang" yang berarti menghadapi dan mengatasi. Kemudian istilah ini ditambah dengan awalan "me" dan akhiran "i", sehingga menjadi "menanggulangi" yang berarti proses, cara dan perbuatan menanggulangi ${ }^{57}$. Istilah "menanggulangi" jika ditinjau dari fungsi dan kegunaannya dalam perspektif dakwah melalui bimbingan dan konseling Islam merujuk pada fungsi membantu seseorang mencegah timbulnya masalah bagi dirinya dan orang lain (preventif), memperbaiki masalah yang sedang dihadapi (kuratif), menjaga agar situasi yang telah membaik tidak kembali lagi (preservatif), dan mengembangkan situasi yang telah baik agar tetap baik atau menjadi lebih baik (developmental) ${ }^{58}$.

Untuk merealisasikan fungsi di atas, para juru dakwah (dā'iyāt) tidak cukup hanya mengedepankan daya intelektual dan berdiam diri saja. Jauh dari itu, para juru dakwah (dā'iyāt) dituntut untuk dapat mengemas dakwah agar dapat menjadi problem solving di tengah masyarakat. Sudah barang tentu, menjadi problem solving di sini tidak sekedar duduk dan datang di tengah masyarakat. Tetapi menjadi betul-betul memahami apa yang dibutuhkan oleh masyarakat. Seperti dalam pemikiran Nurcholish

54 W.A. Gerungan, "Psikologi Sosial", (Jakarta: PT. Eresco, 1988), hlm. 135

55 Muhammad Abū al-Fath al-Bayānūnī, "al-Madkhal ilā 'Ilm ad-Da'wah: ...", hlm. 153

56 as-Syaikh 'Alī Maḥūū, "Hidāyat al-Mursyidīn ...", hlm. 87

57 http://kbbi.web.id.: diakses tanggal 7 Mei 2016

58 Baidi Bukhori, "Dakwah Melalui Bimbingan dan Konseling Islam", Jurnal Konseling Religi, Vol.5, No.1, Juni, 2014, hlm. 11 
Madjid yang tertuang dalam bukunya "Islam Doktrin dan Peradaban, Sebuah Telaah Kritis Tentang Masalah Keimanan, Kemanusiaan, dan Kemodernan", sebagai berikut:

Partisipasi itu merupakan bagian dari perintah Allah untuk menganjurkan kebaikan dan mencegah kejahatan yang cukup banyak disebutkan dalam Kitab Suci. Berkenaan dengan ini, salah satu ilustrasi tentang masyarakat kaum beriman ialah demikian: "Kaum beriman lelaki dan kaum beriman perempuan itu adalah sebagian mereka pelindung bagian yang lain: mereka saling menganjurkan kebaikan dan mencegah kejahatan, menegakkan salat, mengeluarkan zakat, dan mentaati Allah dan Rasul-Nya. Mereka itulah yang mendapat rahmat Allah. Sesungguhnya Allah itu Maha Mulia lagi Maha Bijaksana" (QS. at-Taubah: 71). Ungkapan "Sebagian dari mereka adalah pelindung sebagian yang lain" adalah ungkapan Kitab Suci yang persis sejalan dengan sabda Nabi Muhammad Saw. "Semua kamu adalah pemegang tanggungjawab dan setiap pemegang tanggungjawab akan ditanya tentang tanggungjawabnya". Atau, dalam istilah yang telah dikenal, "setiap ra'i akan diminta pertanggungjawabannya atas ra'iyyah (rakyat)-nya". Maka sebagai seorang Muslim yang baik harus ikut serta melibatkan diri dalam usaha bersama mengembangkan masyarakat kearah yang lebih baik. Dan inilah pangkal tolak partisipasi sosialkeagamaan. Etos keaktifan dalam masyarakat itu merupakan salah satu sifat utama masyarakat Islam, yang seperti diamati oleh Bellah bersesuaian dengan etos zaman modern ${ }^{59}$.

Oleh karena itu, menjadi problem solving tidak hanya sekedar melaksanakan ceramah atau hanya menyampaikan teori-teori keagamaan seperti yang sedang marak sekarang ini, tapi lebih dari itu, para juru dakwah (d $\left.\bar{a}^{\prime} i y \bar{a} t\right)$ dituntut mempunyai peran yang lebih pada konsepsi riil agar dapat menjawab kebutuhan masyarakat era globalisasi sehingga mereka tidak lagi terjerumus pada perilaku patologis seperti pengalahgunaan Napza dan lain sebagainya. Peran-peran yang dimaksud antara lain:

59 Nurcholish Madjid, "Islam Doktrin dan Peradaban: Sebuah Telaan Kritis tentang Masalah Keimanan, Kemanusiaan, dan Kemodernan", (Jakarta: Paramadina, 2000), hlm. 569 


\section{1) Peran $D \bar{a} ’ i$ sebagai Pengganti Orang Tua Asuh}

Peran $d \bar{a}^{\prime} i$ yang pertama ini bisa berfungsi mencegah terjadinya perilaku patologis. Peran sebagai orang tua asuh juga berfungsi menjaga dan mengembangkan keadaan mad'ū agar tetap sehat dan tidak terjerumus kembali dalam perilaku patologis.

Setiap orang tua adalah "madrasah pertama" bagi anak-anaknya karena dari mereka pendidikan anak dimulai. Dari orang tualah seorang anak belajar mengenal segala hal yang baru dalam hidupnya. Belajar berbicara, menimba ilmu dan adab yang mulia, serta menempa kepribadiannya demi mengarungi kehidupan yang luas bagai samudera. Maka sehebat apapun sekolah di luar, tetap belum ada yang dapat menyaingi kehebatan orang tua dalam menentukan kepribadian anakanaknya ke depan.

Sebagai pengganti orang tua, $d \bar{a}^{\prime} i$ dituntut untuk dapat memainkan peran orang tua yang bertanggungjawab dalam memberikan nafkah kepada anaknya secara lahir dan batin. Pemberian nafkah secara lahir bisa dilakukan dalam bentuk pemberian bantuan kepada mad'ü yang sedang menghadapi masalah sosial, seperti: menjalin kerjasama dengan pengusaha untuk memberikan lapangan pekerjaan bagi pengangguran, menjalin kerjasama dengan pihak sekolah untuk pemberian beasiswa pendidikan bagi warga miskin, pembentukan dompet dhu'afa, menjalin kerjasama dengan pihak medis untuk pengobatan gratis, dan lain sebagainya. Kemudian, dalam hal pemberian nafkah secara batin bisa dilakukan dalam bentuk pemenuhan kebutuhan psikisnya, seperti: kebutuhan rasa kasih sayang, rasa aman, rasa harga diri, rasa ingin bebas, kebutuhan aktualisasi diri, kebutuhan sosial, agama ${ }^{60}$, dan lain sebagainya. Atau pemberian nafkah batin bisa dilakukan lewati pemberian pengetahuan keagamaan yang benar dan pengawasan pelaksanaan ibadah-ibadah ritual harian ${ }^{61}$.

Dengan berperan sebagai pengganti orang tua asuh yang senantiasa memberikan "nafkah" dalam berdakwah, dapat dipastikan $d \bar{a}^{\prime} i$ dapat mendekati dan menimbulkan kenyamanan bagi para korban perilaku patologis. Ketika kedekatan sudah tercipta, maka dā'i dapat mencari informasi tentang faktor dominan penyebab terjadinya perilaku patologis tersebut dan kemudian mulai menjadi problem solving baginya.

\section{2) Peran $D \bar{a} ' i$ sebagai Pembimbing}

60 Hasyim Muhammad, "Dialog Antara Tasawuf dan Psikologi: Telaah atas Pemikiran Psikologi Humanistik Abraham Maslow", (Yogyakarta: Pustaka Pelajar, 2002), hlm. 77

61 Muhammad 'Abd al-'Azīz Ibrāhīm Dāud, "at-Tabșurah fi Fiqh ad-Da'wah wa adDā'iyah", hlm. 67 
Di era globalisasi ini, dā'i dalam berdakwah juga dituntut untuk dapat berperan menjadi pembimbing. Peran ini dalam proses dakwah melalui bimbingan dan konseling Islam berfungsi untuk menyembuhkan mad'ū dari perilaku patologis, serta menjaga keadaan mad'ū agar tetap baik dan tidak terjerumus kembali pada perilaku patologis. Dalam memainkan peranannya sebagai pembimbing, $d \bar{a}^{\prime} i$ dituntut untuk dapat: 1) memahami kondisi minat, mental, moral dan spiritual mad'ü, sehingga aktifitas penyembuhan dari perilaku patologis dan pembelajaran hidup dapat terlayankan dengan tepat dan terarah. 2) membangun dan mengembangkan motivasi belajar mad'ū agar memiliki upaya kuat untuk berihktiar secara terus menerus tanpa mengenal rasa putus asa, gigih dalam berusaha sampai mencapai tujuannya. 3) membimbing dan mengarahkan nafs mad'ü ke tingkatan nafs yang positif sehingga mad'ü dapat berkeyakinan diri yang kuat, berpola pikir positif, bersikap dan pola laku yang produktif dengan berparadigma pada wahyu Tuhan, sabda rasul dan keteladanannya. 4) memberikan keteladanan yang baik dan benar dalam berkeyakinan, cara berpola pikir, pola rasa, pola sikap dan perilaku yang benar dalam kehidupan sehari-hari di lingkungannya. 5) menjaga, mengontrol, memelihara dan melindungi masyarakat secara lahir dan batin, serta memberikan mediasi, bimbingan atau layanan konseling secara memadai ${ }^{62}$.

\section{3) Peran $D \bar{a} ' i$ sebagai Konselor Teman Sebaya}

Istilah konselor teman sebaya muncul pada tahun 1939 untuk membantu penderita alkoholik. Pada dasarnya, konsep teman sebaya merupakan suatu cara bagi para remaja untuk belajar bagaimana memperhatikan dan membantu teman sebayanya dalam kehidupan seharihari63. Peran $d \bar{a}^{\prime} i$ sebagai konselor teman sebaya di era globalisasi ini menjadi penting sebab: 1) Hanya sebagian kecil masyarakat yang memanfaatkan dan bersedia berkonsultasi/berkomunikasi langsung dengan $d \bar{a}^{\prime} i$ /konselor/tokoh masyarakat. Mereka lebih sering berkomunikasi dengan teman sebaya yang bisa dipercaya dapat menjaga rahasia serta dapat membantu memecahkan problematika kehidupannya. 2) Berbagai kajian secara konsisten menunjukkan bahwa dikalangan remaja, kesepian atau kebutuhan akan teman merupakan sesuatu yang

62 Hamdani Bakran adz-Dzakey, "Kecerdasan Kenabian", (Yogyakarta: Pustaka alFurqan, 2007), hlm. 646

${ }^{63}$ R.A. Carr, "Theory and Practice of Peer Counseling", (Ottawa: Canada Employmen and Immigration Commision, 1981), hlm. 3 
menjadi perhatian dan kebutuhan mereka. Hubungan pertemanan bagi remaja seringkali menjadi sumber terbesar bagi terpenuhinya rasa senang, dan juga dapat menjadi sumber frustasi yang paling mendalam. Kenyataan ini menunjukkan bahwa teman sebaya memungkinkan untuk saling membantu satu sama lain dengan cara yang unik dan tidak dapat diduga oleh para orang tua dan pendidik ${ }^{64}$.

Untuk bisa berperan sebagai konselor teman sebaya, dā'i dituntut untuk dapat memenuhi prinsip-prinsip konseling teman sebaya, di antaranya: 1) Harus bisa menjaga rahasia, 2) Menghormati keyakinan, hakhak dan harapan masyarakat, 3) Tidak ada justifikasi, yang ada hanya penyampaian dan pengajaran yang dikemas dalam bentuk informasi, bukan nasehat, 4) Didasarkan pada kesetaraan65.

Dengan berperannya $d \bar{a}^{\prime} i$ sebagai konselor teman sebaya, diharapkan $d \bar{a}^{\prime} i$ dapat menyembuhkan para pelaku penyimpangan, serta menjaga kesembuhannya supaya tidak kembali lagi pada perilaku menyimpang.

\section{Penutup}

\section{Kesimpulan}

Temuan dalam kajian ini setidaknya telah menunjukkan bahwa keanekaragaman masyarakat yang akan dihadapi oleh $d \bar{a}^{\prime} i$ di era globalisasi menuntut adanya upaya untuk menciptakan konsep dakwah Islam yang relevan dengan keanekaragaman obyeknya. Untuk itu, bahasa aplikasi dakwah mestilah terletak pada kearifan para petugas dakwah dengan cara mengenal karakteristik dan tipologi masyarakat yang dihadapinya. Setiap $d \bar{a}^{\prime} i$ wajib membahasakan sabda Tuhan (al-Qur'an) sesuai dengan kemampuan pikiran (daya nalar) mad'ū. Maka model dakwah melalui pendekatan psikologis menjadi penting untuk diterapkan di era globalisasi.

Kemudian seperti dijelaskan di atas, globalisasi adalah era di mana akses keluar masuk suatu negara semakin mudah, sehingga nilai-nilai antar agama dan budaya terjadi pergesekan dan pergeseran. Walhasil, masyarakat era ini seringkali menghadapi persoalan makna hidup, karena tekanan yang amat berlebihan kepada segi keterikatan terhadap peristiwaperistiwa tragis dalam kehidupan pribadi dan sosial. Maka tidak mengherankan jika mereka seringkali menjadi gelisah dan merasakan ketegangan batin. Kegelisahan dan ketegangan batin itu mendorongnya

64 R.A. Carr, "Theory and Practice of Peer Counseling", hlm. 5

65 R.A. Carr, "Theory and Practice of Peer Counseling", hlm. 13 
untuk melakukan sesuatu, supaya dapat menghilangkan rasa yang tidak enak itu. Apabila tidak mampu memenuhinya, terkadang ia lalu mencari kepuasan dengan cara yang tidak wajar, sehingga menimbulkan perilaku patologis seperti penyalahgunaan Napza.

Dan untuk menanggulangi perilaku patologis sebagai dampak negatif globalisasi, maka dā'i dalam kegiatan dakwahnya dituntut untuk mempunyai peran yang solutif-partisipatif dalam menyelesaikan problematika sosial yang dihadapi oleh mayoritas masyarakat era globalisasi. Peran-peran tersebut meliputi: 1) Peran $d \bar{a} ' i$ sebagai pengganti orang tua asuh. 2) Peran $d \bar{a}^{\prime} i$ sebagai pembimbing. 3) Peran $d \bar{a}^{\prime} i$ sebagai konselor teman sebaya.

\section{Saran dan Rekomendasi}

Menyadari keterbatasan kajian ini dalam mengungkapkan peran $d \bar{a}^{\prime} i$ dalam menanggulangi perilaku patologis, maka diperlukan kajian lebih lanjut pada dataran pengembangan teoritik dakwah menurut levelnya dan dataran empirik mengenai dakwah melalui bimbingan dan konseling Islam yang bertujuan membawa umat manusia ke arah yang lebih baik. Selain itu juga penting diteliti lebih lanjut tentang batasan perilaku patologis dan faktor-faktornya, apakah perilaku patologis lebih dominan disebabkan oleh faktor nafs ataukah faktor lingkungan? Dengan mengetahui hal itu, $d \bar{a}^{\prime} i$ dapat merumuskan strategi dakwah yang terbaik dalam upaya penanggulangan perilaku patologis.

Dan akhir kata, perkenankanlah penulis meminta maaf jika terdapat banyak kekurangan dalam penulisan makalah ini. Saran dan kritik yang membangun sangat kami harapkan. Hadānāllāhu wa iyyākum ilā sabīlil Haq. 


\section{DAFTAR PUSTAKA}

Abū Karam, Karam Amīn, "Haqīqat al-'Ibādah 'inda Muhyī ad-Dīn Ibnu 'Arabī”, (Kairo: Dār al-Amīn, 1997)

Arifin, "Psikologi Dakwah: Suatu Pengantar Studi", (Jakarta: Bumi Aksara, 1991)

Azra, Azyumardi, "Konflik Baru Antarperadaban: Globalisasi, Radikalisme, dan Pluralitas", (Jakarta: PT. Raja Grafindo Persada, 2002)

Badawī (al), Hasan 'Abd ar-Ra'ūf Muhammad, "Fiqh ad-Da'wah alIslāmiyyah", (Kairo: Maktabah Azhariyyah, 1987)

Bayānūnī (al), Muhammad Abū al-Fatḥ, "al-Madkhal ilā 'Ilm ad-Da'wah: Dirāsah Manhajiyyah Syāmilah li Tārīkhi ad-Da'wah wa Ușūlihā wa Manāhijihā wa Asālībihā wa Wasāilihā wa Musykilātihā fì Daui anNaqli wa al-'Aqli", cet. ke-3, (Beirut: Muassasah ar-Risālah, 1995)

Berry, David, "Pokok-Pokok Pikiran dalam Sosiologi", (Jakarta: Raja Grafindo Persada, 1995)

Bukhori, Baidi, "Dakwah Melalui Bimbingan dan Konseling Islam", Jurnal Konseling Religi, Vol.5, No.1, Juni, 2014

Carr, R.A., "Theory and Practice of Peer Counseling", (Ottawa: Canada Employmen and Immigration Commision, 1981)

Dāud, Muhammad 'Abd al-'Azīz Ibrāhīm, "at-Tabșurah fi Ffiqh ad-Da'wah wa ad-Dā'iyah", (Zaqāziq: Maktabah Jāmi'ah al-Azhar, T.tt)

Departemen Pendidikan Nasional, "Kamus Besar Bahasa Indonesia", (Jakarta: Balai Pustaka, 2002)

Dzakey (adz), Hamdani Bakran, "Kecerdasan Kenabian", (Yogyakarta: Pustaka al-Furqan, 2007)

Gerungan, W.A., "Psikologi Sosial", (Jakarta: PT. Eresco, 1988)

Hāsyim, Ahmad 'Umar, "Manhaj al-Islām fi al-'Aqīdah wa al-'Ibādah wa alAkhlāq", (Kairo: Dār Nahḍah Mișr, 1997)

Hātim, Muhammad 'Abd al-Qādir, "al-'Aulamah Mā Lahā wa Mā 'Alaihā", (Kairo: al-Haiah al-Mișriyah al-'Āmah li al-Kitāb, 2005)

Ḥusain, Muhammad al-Khuḍri, "ad-Da'wah ilā al-Ișlāḥ", (Kairo: al-Mațba'ah as-Salafiyyah, $1346 \mathrm{H}$ ) 
http://kbbi.web.id.: 7 Mei 2016

Ibnu 'Arabī, Muhyī ad-Dīn, "al-Futūḥāt al-Makkiyyah", Taḥīq: 'Uṡmān Yahyā, cet. ke-2, (Kairo: al-Haiah al-Mișriyah al-'Āmah li al-Kitāb, 1985)

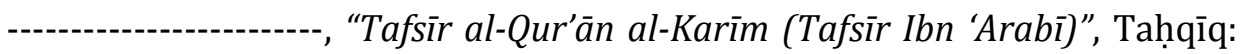
'Abd al-Wāris̉ Muhammad 'Alī, (Beirut: Dār al-Kutub al-'Ilmiyyah, 2006)

, "al-Futūhāt al-Makkiyyah", Taḥīq: Nawwāf al-Jarrāḥ, cet. ke-2, (Beirut: Dār Șādir, 2007)

Ibnu Manzūr, "Lisān al-'Arab", Taḥīiq: 'Abdullāh 'Alī al-Kabīr, Muhammad Ahmad Hasbullāh dan Hāsyim Muhammad as-Syāżilī, (Kairo: Dār alMa'ārif, T.tt)

Kartono, Kartini, "Patologi Sosial 1", cet. ke-11, (Jakarta: Rajawali Grafindo, 2009)

Khatimah, Khusnul, "Islam dan Globalisasi: Sebuah Pandangan Universalitas Islam", Jurnal Komunika STAIN Purwokerto, Vol. 3, No.1, Januari-Juni, 2009

Madjid, Nurcholish, "Islam Doktrin dan Peradaban: Sebuah Telaan Kritis tentang Masalah Keimanan, Kemanusiaan, dan Kemodernan", (Jakarta: Paramadina, 2000)

Maḥfūz, as-Syaikh 'Alī, "Hidāyat al-Mursyidīn ilā Țuruq al-Wa'ẓi wa alKhațābah", cet. ke-9, (Kairo: Dār al-I'tișām, 1979)

Mubarok, Achmad, "Psikologi Dakwah: Membangun Cara Berfikir dan Merasa", (Malang: Madani Press, 2014)

Muhammad, Hasyim, "Dialog Antara Tasawuf dan Psikologi: Telaah atas Pemikiran Psikologi Humanistik Abraham Maslow", (Yogyakarta: Pustaka Pelajar, 2002)

Narwoko, J. Dwi dan Bagong Suyanto, "Sosiologi: Teks Pengantar dan Terapan", (Jakarta: Kencana, 2007)

Neubeck, Kenneth J., Neubeck, Mary Alice, Glasberg, and Davita Silfen, "Social Problem (a Critical Approach)", (New York: McGraw-Hill, 1980)

Noer, Kautsar Azhari, "Ibn 'Arabi: Wahdat al-Wujud dalam Perdebatan", (Jakarta: Paramadina, 1995) 
Northcott, Michael S., "Pendekatan Sosiologis", dalam Peter Connoly (ed), "Aneka Pendekatan Studi Agama", Terjemahan Indonesia: Imam Khoiri, cet. ke-2, (Yogyakarta: LKiS Group, 2002)

Rahmawati, Novia, "Konsep Perencanaan dan Perancangan Pusat Terapi dan Rehabilitasi bagi Ketergantungan Narkoba dengan Pendekatan Arsitektur Perilaku", Tesis tidak dipublikasikan, (Surakarta: Universitas Sebelas Maret, 2010)

Rakhmat, Jalaluddin, "Psikologi Komunikasi", (Bandung: Remaja Karya, 2009)

Rāzī (al), Muhammad Fakhr ad-Dīn, "Mafātiḥ al-Ġaib", j.8 dan 20, (Beirut: Dār al-Fikr, T.tt)

Sambas, Syukriadi, "Pemikiran dakwah Muhammad Abduh dalam Tafsir alMannar", Disertasi tidak dipublikasikan, (Jakarta: Sekolah Pascasarjana UIN Syarif Hidayatullah, 2009)

Soetomo, "Masalah Sosial dan Upaya Pemecahannya", (Yogyakarta: Pustaka Pelajar, 2008)

Surachman, Dicky, "Pengaruh Penyimpangan Seksual dalam perilaku dan Pola Pikir Siswa terhadap Prestasi Belajar pada Mata Pelajaran Pendidikan Agama Islam di SMPN 1 Kabupaten Cirebon", Tesis tidak dipublikasikan, (Cirebon: Program Pascasarjana IAIN Syekh Nurjati, 2011)

Zaidān, 'Abd al-Karīm, "'Ușūl ad-Da'wah", cet. ke-3, (Bag̀dād: Dār at-Turāś, 1976) 